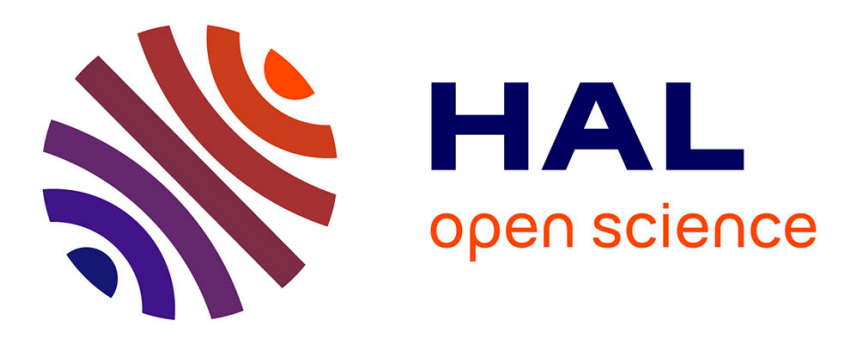

\title{
A parameterization of the specific surface area of seasonal snow for field use and for models of snowpack evolution
}

Florent Domine, Anne-Sophie Taillandier, William R. Simpson

\section{- To cite this version:}

Florent Domine, Anne-Sophie Taillandier, William R. Simpson. A parameterization of the specific surface area of seasonal snow for field use and for models of snowpack evolution. Journal of Geophysical Research, 2007, 112 (F02031), 1 à 13 p. 10.1029/2006JF000512 . insu-00376230

HAL Id: insu-00376230

https://hal-insu.archives-ouvertes.fr/insu-00376230

Submitted on 11 Mar 2021

HAL is a multi-disciplinary open access archive for the deposit and dissemination of scientific research documents, whether they are published or not. The documents may come from teaching and research institutions in France or abroad, or from public or private research centers.
L'archive ouverte pluridisciplinaire $\mathbf{H A L}$, est destinée au dépôt et à la diffusion de documents scientifiques de niveau recherche, publiés ou non, émanant des établissements d'enseignement et de recherche français ou étrangers, des laboratoires publics ou privés. 


\title{
A parameterization of the specific surface area of seasonal snow for field use and for models of snowpack evolution
}

\author{
F. Domine, ${ }^{1}$ A.-S. Taillandier, ${ }^{1}$ and W. R. Simpson ${ }^{2,3}$ \\ Received 29 March 2006; revised 18 January 2007; accepted 15 March 2007; published 13 June 2007.
}

[1] The specific surface area (SSA) of snow is needed to model air-snow exchange of chemical species. SSA is related to many snow physical properties, such as albedo and permeability. However, it is not described in models of snowpack evolution, in part because it is difficult to measure. Snowpack models often predict snow grain shape and snow density, and the goal of this paper is to propose parameterizations of snow SSA, based on snow density and grain shape. SSA values of 345 snow samples from snowpacks of the Alpine, maritime, tundra and taiga types are presented. Samples are regrouped into three main types: fresh $(\mathrm{F})$, recent $(\mathrm{R})$, and aged (A) snows, with several subtypes referring to grain shapes. Overall, there is a clear inverse correlation between SSA and density, $d$. Empirical equations of the form $\mathrm{SSA}=\mathrm{A} \ln (d)+\mathrm{B}$ are proposed for the $\mathrm{F}$ and $\mathrm{R}$ types. For aged snows, separate correlations are proposed for subtypes A1 (rounded grains), A2 (faceted crystals), A3 (depth hoar), and A4 (lightly melted snow). Within subtypes $\mathrm{A} 1, \mathrm{~A} 2$, and $\mathrm{A} 3$, more elaborate classifications are made by considering the snowpack type (Alpine, taiga, or tundra). For A1, A2, and A3 types, different trends are related to different intensities of wind action, which increases in the order taiga, Alpine, and tundra. We finally propose three parameterizations of snow SSA with increasing sophistication, by correlating SSA to snow type, then to snow type and density, and finally to snow type, density, and snowpack type.

Citation: Domine, F., A.-S. Taillandier, and W. R. Simpson (2007), A parameterization of the specific surface area of seasonal snow for field use and for models of snowpack evolution, J. Geophys. Res., 112, F02031, doi:10.1029/2006JF000512.

\section{Introduction}

[2] The specific surface area (SSA) of snow is its surface area accessible to gases per unit mass [Legagneux et al., 2002]. SSA is a physical variable that is crucial to understand both the chemistry [Dominé and Shepson, 2002] and the physics [Legagneux et al., 2002] of the snowpack. Among many examples of its usefulness, many semivolatile chemical species such as persistent organic pollutants (POPs) are thought to adsorb onto snow surfaces [Daly and Wania, 2004; Herbert et al., 2005a, 2005b] and quantifying their amounts in snow and their exchanges with the atmosphere requires the knowledge of snow SSA and its variations. The albedo of snow has been shown to be related to grain size [Warren, 1982], but the definition of snow grain size is not simple [e.g., Aoki et al., 2000]. A potentially better description of grain size is its specific surface area, as already suggested by Warren [1982]. Domine et al. [2006] have recently shown that snow albedo in the IR

\footnotetext{
${ }^{1}$ Laboratoire de Glaciologie et Géophysique de l'Environnement, CNRS, Saint-Martin d'Hères, France.

${ }^{2}$ Geophysical Institute, University of Alaska Fairbanks, Fairbanks, Alaska, USA.

${ }^{3}$ Department of Chemistry, University of Alaska Fairbanks, Fairbanks, Alaska, USA.

Copyright 2007 by the American Geophysical Union. 0148-0227/07/2006JF000512
}

could indeed be well correlated with snow SSA. Airflow through snow, and hence the efficiency of air-snow exchanges [Albert et al., 2002] is determined in part by the air permeability of snow that depends on air friction on the surface of snow crystals [Jordan et al., 1999]. Most models describing the air permeability of snow use grain size to predict its value, but it is likely that SSA would be a more appropriate variable.

[3] Snow SSA has seen little use in snow physics and chemistry, both in field studies and models, because its measurement is difficult and time consuming, the main reliable method established at present for routine use being methane adsorption at $77 \mathrm{~K}$ [Dominé et al., 2001; Legagneux et al., 2002]. It is also for the moment difficult to predict the evolution of snow SSA during metamorphism. Models have been proposed under isothermal conditions, on the basis of the concept of Ostwald ripening, but difficulties have been encountered because the normalized distribution of grain size is not at steady state in the seasonal snowpack, and the equations of Ostwald ripening therefore cannot be used in a simple manner [Legagneux et al., 2004; Legagneux and Domine, 2005]. Empirical equations have been proposed [Cabanes et al., 2002, 2003] but the relationship between these empirical rates and environmental variables such as temperature, temperature gradient and wind speed is not well understood, which limits their application. Recently, Flanner and Zender [2006] have proposed a physically based model of SSA evolution that 
is valid under both isothermal and temperature gradient conditions. They approximate snow crystals as spheres, and use adjustable parameters to solve the difficulties encountered by Legagneux and Domine [2005]. Their sophisticated model is not very simple to use, however, and still requires experimental validation for many environmental conditions. In any case, given the present difficulty in parameterizing snow SSA in models, authors modeling the air-snow exchange of POPs adsorbed onto snow surfaces during the metamorphism of a snow layer used oversimplified approximations, such as a linear decrease in SSA with time [Daly and Wania, 2004].

[4] Understanding its time evolution is not the only SSArelated question snow studies have to face. Often, chemical analyses of a snowpack whose detailed history is unknown are performed, and the chemical interpretation requires the knowledge of snow SSA. For example, Herbert et al. [2005a, 2005b] tried to interpret the concentrations of persistent organic pollutants (POPs) in Arctic snow. They found a correlation between POP concentrations and snow density and concluded that this correlation was probably due to a correlation between SSA and density. It is therefore clear that a more detailed interpretation could have been made if these authors had used a reliable method to measure or estimate SSA. To assist in these types of studies, we wish to propose here a method to estimate SSA from snow variables that can be easily and rapidly determined in the field. An additional objective of this work is that contrary to the objectives of physically based approaches [Legagneux et al., 2004; Legagneux and Domine, 2005; Flanner and Zender, 2006], we wish to propose a method that does not require the knowledge of the age of the snow sample.

[5] SSA is clearly determined by a large number of physical variables but following Legagneux et al. [2002] we propose to estimate its value from an examination of the snow crystal type and from a measurement of snow density. Besides its field use, this method can simply be incorporated in current models of snowpack evolution, such as CROCUS [Brun et al., 1992] and SNOWPACK [Lehning et al., 2002] that predict snow density and crystal type.

[6] Legagneux et al. [2002] presented a compilation of 176 SSA values, proposed a classification of snow types adapted to the determination of SSA, and gave a densitySSA correlation for each snow type, which allowed the estimation of snow SSA within 25 to $40 \%$ at the $1 \sigma$ confidence level. Since then, we have increased the number of measurements to 345 , significantly improving the statistical value of many correlations. Our previous compilation was based on studies of snow in the Alps and the Arctic, thus dealing with snowpacks of the tundra, Alpine and maritime types according to the classification of Sturm et al. [1995]. We have now performed many measurements in central Alaska, which allowed us to characterize the SSA of the taiga snowpack. We have also done measurements on snow layers affected by numerous melt-freeze cycles, which have very low SSAs. We further indicate correspondence between our snow type classification and that recommended by the International Classification of Seasonal Snow on the Ground (ICSSG) [Colbeck et al., 1990], although the latter one is not very well adapted to the description of SSA. Finally, we have detected and corrected an artifact in our previous protocol, which improves the reliability of our method.

\section{Methods}

[7] The method has been extensively detailed by Legagneux et al. [2002] and only the principle and recent modifications will be described. The principle is to measure the adsorption isotherm of methane on the snow sample at liquid nitrogen temperature, $77 \mathrm{~K}$, using a volumetric method while snow is contained in stainless steel containers of volumes in the range $100-250 \mathrm{~cm}^{3}$. A Brunauer-Emmett-Teller (BET) mathematical treatment [Brunauer et al., 1938] is then applied to the isotherm to determine the surface area of the sample and the mean heat of adsorption of the first

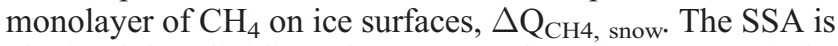
obtained by dividing the measured surface area of the sample by its mass.

[8] Since the compilation of Legagneux et al. [2002], an experimental artifact has been detected. The SSA of dry snow is usually in the range $80-1500 \mathrm{~cm}^{2} \mathrm{~g}^{-1}$, while the snow samples used weigh 15 to 50 grams. Thus the surface area of the sample is around 0.2 to $2 \mathrm{~m}^{2}$. As briefly alluded to by Legagneux et al. [2004], we found that adsorption of $\mathrm{CH}_{4}$ on the stainless steel walls of the vacuum container used for the measurement was not always negligible. We thus measured the adsorption isotherm of $\mathrm{CH}_{4}$ on the walls of each container used and found that the surface areas of the containers were around $1000 \mathrm{~cm}^{2}$ and that $\Delta \mathrm{Q}_{\mathrm{CH} 4 \text {,stainlesssteel }}=1300 \mathrm{~J} \mathrm{~mol}^{-1}$. We then reinterpreted the molar budgets of the volumetric measurements in terms of adsorption on both the snow and the stainless steel. Using this data analysis method, the snow SSA values were usually reduced by 6 to $12 \%$ with the containers used by Legagneux et al. [2002]. In our studies in Alaska, we used smaller containers to improve pumping speed during the measurements. This reduced the surface ratio between the snow and the stainless steel, and the correction, while still less than $10 \%$ for most samples, reached $50 \%$ for samples with a surface area less than $0.2 \mathrm{~m}^{2}$, which concerns mostly snow having undergone melt-freeze cycles and aged depth hoar.

[9] Because $\Delta \mathrm{Q}_{\mathrm{CH} 4 \text {,stainlesssteel }}$ is much lower than $\Delta \mathrm{Q}_{\mathrm{CH} 4 \text {,snow }}$, uncorrected measurements yield a lower value

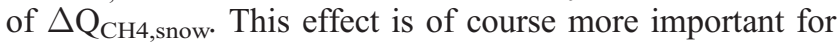
samples with a low surface area, and without correction, $\Delta \mathrm{Q}_{\mathrm{CH} 4}$, snow is an increasing function of the surface area of the snow sample, tending asymptotically toward the true $\Delta \mathrm{Q}_{\mathrm{CH} 4 \text {,snow }}$ value, as observed by Dominé et al. [2000]. After correction, the correlation between $\Delta \mathrm{Q}_{\mathrm{CH} 4 \text {,snow }}$ and surface area disappears, and there is just more scatter of $\Delta \mathrm{Q}_{\mathrm{CH} 4 \text {,snow }}$ values at low surface areas, around a mean value $\Delta \mathbf{Q}_{\mathrm{CH} 4 \text {,snow }} \pm 1 \sigma=2540 \pm 200 \mathrm{~J} \mathrm{~mol}^{-1}$. Legagneux et al. [2002] proposed that the value of $\Delta \mathrm{Q}_{\mathrm{CH} 4 \text {,snow }}$ be used as a test for the reliability of the measurement, and recommended $\Delta \mathrm{Q}_{\mathrm{CH} 4 \text {, snow }}=2240 \pm 200 \mathrm{~J} \mathrm{~mol}^{-1}$. After the discovery of this new artifact, we now recommend the value $\Delta \mathrm{Q}_{\mathrm{CH} 4 \text {, snow }}=2540 \pm 200 \mathrm{~J} \mathrm{~mol}^{-1}$.

[10] There is still a significant scatter in $\Delta \mathrm{Q}_{\mathrm{CH} 4 \text {,snow }}$ values. A lot of our measurements were focused on the monitoring of the SSA of identified snow layers, either in the field [Cabanes et al., 2002, 2003] or in the laboratory 
[Legagneux et al., 2003, 2004] and we observed that some layers had, after correction, systematically low values, while others had high values. The scatter within a given layer whose SSA was measured 5-15 times over a few months was usually $60 \mathrm{~J} \mathrm{~mol}^{-1}$, and we therefore suspect that variations in $\Delta \mathrm{Q}_{\mathrm{CH} 4 \text {,snow }}$ may be caused by different snow chemical compositions, with a fraction of the impurities being in the adsorbed state. Another possibility is that different snow samples have different predominant crystallographic faces, with different $\Delta \mathrm{Q}_{\mathrm{CH} 4 \text {,snow }}$ values, but this is not supported by the work of Chaix et al. [1996] and Chaix and Dominé [1997]. A last possibility is of course experimental error, and in particular variations in the configuration of the volumetric system. We indeed observed that after rebuilding the system and changing various containers, the average $\Delta \mathrm{Q}_{\mathrm{CH} 4 \text {,snow }}$ could be modified by as much as $100 \mathrm{~J} / \mathrm{mol}$. We believe that this is due to error in the measurement of the various volumes, to which $\Delta \mathrm{Q}_{\mathrm{CH} 4 \text {,snow }}$ is very sensitive. In conclusion, there seems to be several causes that can explain the large variability of $\Delta \mathrm{Q}_{\mathrm{CH} 4 \text {,snow, but our data }}$ suggest that for a given configuration of a measurement system, the standard deviation in $\Delta \mathrm{Q}_{\mathrm{CH} 4 \text {,snow }}$ should be less than $100 \mathrm{~J} / \mathrm{mol}$.

[11] We found an excellent linear correlation between uncorrected and corrected surface areas of the sample $\left(\mathrm{R}^{2}=\right.$ $0.999990): \mathrm{SA}_{\text {corrected }}=1.0014 \times \mathrm{SA}_{\text {uncorrected }}-902 \mathrm{~cm}^{2}$. Hence we deduced that an excellent approximation of the correction is to subtract 0.9 times the surface area of the stainless steel container from the uncorrected snow surface area to obtain what we believe is the correct value. The factor 0.9 is caused by the less energetic adsorption of $\mathrm{CH}_{4}$ on stainless steel than on ice.

[12] The reproducibility of the method, obtained by successive SSA measurements by two experimentalists studying several snow samples, as detailed by Legagneux et al. [2002] is $2 \sigma=6 \%$. Including an estimate of systematic errors, the overall method accuracy is $12 \%$ [Legagneux et al., 2002].

\section{Results and Discussion}

\subsection{SSA Values}

[13] We present here 345 SSA values from seasonal snowpacks.

[14] 1. One-hundred-five SSA values are from the French Alps sampled at elevations between 1320 and $2890 \mathrm{~m}$, in snowpacks of the maritime and Alpine types.

[15] 2. One-hundred-eleven samples are from the Arctic, sampled around Alert (Canadian high Arctic, $82.5^{\circ} \mathrm{N}$, 67 samples), Barrow (Alaska, $71^{\circ} \mathrm{N}, 11$ samples) and $\mathrm{Ny}$ Ålesund (Svalbard, $79^{\circ} \mathrm{N}, 33$ samples). At Alert and Barrow, the snowpack is definitely of the tundra type. Near Ny Ålesund, the abundant precipitation due to the vicinity of the Gulf stream, combined with temperatures fairly warm for that latitude, often give the snowpack an Alpine character with thin depth hoar layers, frequent ice layers and snowpack thicknesses exceeding $1 \mathrm{~m}$. In coastal areas, severe wind erosion forms a snowpack closer to the tundra type. Most samples from Ny Alesund are from these coastal areas, and for simplicity all our Svalbard samples are classified as being of the tundra type.
[16] 3. One-hundred-twenty-nine samples from central Alaska, sampled at the Large Animal Research Station of the University of Alaska Fairbanks $\left(65^{\circ} \mathrm{N}, 164^{\circ} \mathrm{W}\right)$, as described in detail by Taillandier et al. [2006]. The snowpack in central Alaska is typical of the taiga type, characterized by the predominance of depth hoar and faceted crystals. Of these samples, 30 were obtained from snow that precipitated on tables, under which air circulation prevented the establishment of high temperature gradients. These experiments reproduce some of the variables to which permanent snow is subjected on ice cap: low temperatures and low temperature gradients. The low gradients on ice caps are the results of the thermal insulation provided by snow layers that accumulate over the years. However, densification caused by the weight of these layers is not reproduced here. Despite this difference, these experiments may yield interesting data that will be difficult to obtain on ice caps, as liquid nitrogen is required for our measurements. Here we observed that snow layers with small rounded grains formed rather than depth hoar, and these were very similar to those encountered in cold Alpine regions with high accumulation. They were also similar to small-grained layers observed in ice caps, and which form mostly in winter [Alley et al., 1997; Dang et al., 1997]. Although the evolution of these snow layers was not entirely natural, they were subjected to variable environmental conditions similar to those found in other natural settings and the trends in density and SSA evolution were similar to cold Alpine snow layers. We have thus decided to include them in this compilation. We have not, however, included data obtained on natural samples evolved in laboratory cold rooms, as described by Legagneux et al. [2003, 2004].

[17] All the values are reported in Table 1 to show the variability, and are grouped by types, as defined by Legagneux et al. [2002]. Typical pictures of this classification are reported by Legagneux et al. [2002]. These types have a lot of features in common with those of the International Classification of Seasonal Snow on the Ground [Colbeck et al., 1990]. However, we found that the ICSSG classification was not always well adapted to describing and understanding SSA. For example, in the ICSSG classification, type 1sd is for stellar dendritic crystals and class 1gp is for graupel. In practice, snowfalls with just stellar dendritic crystals are rare, and these are usually accompanied by crystals with various degrees of riming. In a given snow episode precipitation often alternates between lightly rimed crystals and graupel-like crystals. Sampling the pure 1sd type is therefore a rare opportunity. Another example is that when the air temperature is just above $0^{\circ} \mathrm{C}$, the SSA of falling snow is noticeably reduced while the aspect of snow crystals is little affected and a specific type, F4, had to be defined to account for this class. The main purpose of this classification is to describe snow according to the characteristics that affect its SSA. Whenever possible, we have nevertheless indicated in Table 1 the correspondence between both our and the ICSSG classifications.

[18] Similarly to that of ICSSG, our classification is based on the habit of precipitating particles and/or on the metamorphic history of the crystals. F stands for fresh snow, sampled at the most 24 hours after the fall and before any visible transformation has taken place. This corresponds to 
Table 1. Specific Surface Area, SSA, Values for the 345 Snow Samples Measured, Divided Into 15 Subtypes $^{\mathrm{a}}$

\begin{tabular}{|c|c|c|c|c|c|c|}
\hline $\begin{array}{l}\text { Snow } \\
\text { Type }\end{array}$ & $\begin{array}{c}\text { Subtype } \\
\text { Description }\end{array}$ & $\begin{array}{l}\text { Subtype } \\
\text { Code }\end{array}$ & $\begin{array}{l}\mathrm{SSA} \\
\mathrm{cm}^{2} / \mathrm{g}\end{array}$ & $\begin{array}{l}\text { ICSSG } \\
\text { Type }\end{array}$ & $\begin{array}{c}\text { Mean } \\
\mathrm{SSA} \pm \sigma_{\mathrm{SSA}}\end{array}$ & $\begin{array}{c}\text { Mean } \\
\text { Density } \pm \sigma_{\text {dens }}\end{array}$ \\
\hline \multirow[t]{4}{*}{$\begin{array}{l}\text { Freshly fallen } \\
\text { snow F }\end{array}$} & $\begin{array}{l}\text { dendritic, from lightly } \\
\text { rimed to graupel }\end{array}$ & $\mathrm{F} 1$ & $\begin{array}{l}1313,1231,1029,1026, \\
\text { 1013,961,960,943, } \\
931,917,892,885, \\
857,846,837,672, \\
637,635,630,613, \\
577,561,553\end{array}$ & $1 \mathrm{sd}, 1 \mathrm{gp}$ & $849 \pm 210$ & $0.084 \pm 0.052$ \\
\hline & $\begin{array}{l}\text { small columns, } \\
\text { bullet rosettes }\end{array}$ & $\mathrm{F} 2$ & $\begin{array}{l}1401,768,734,730 \\
\quad 656,565\end{array}$ & $1 \mathrm{cl}$ & $809 \pm 299$ & $0.102 \pm 0.041$ \\
\hline & $\begin{array}{l}\text { small plates, } \\
\text { needles and columns }\end{array}$ & $\mathrm{F} 3$ & $\begin{array}{l}1558,1171,1100,1012, \\
918,887,813,801, \\
748,746,746,717, \\
681,655,645,612, \\
610,607,599,585, \\
571,565,555,526, \\
489,479,469,439, \\
432,424,399,394, \\
376,367,331\end{array}$ & $\begin{array}{l}\text { 1cl, 1nd, } \\
\text { 1pl, 1ir }\end{array}$ & $658 \pm 260$ & $0.108 \pm 0.026$ \\
\hline & air $\mathrm{T}>0{ }^{\circ} \mathrm{C}$ & F4 & $632,552,447,379$ & - & $503 \pm 112$ & $0.148 \pm 0.021$ \\
\hline \multirow[t]{4}{*}{$\begin{array}{l}\text { Snow with } \\
\text { recognizable } \\
\text { particles } \mathrm{R}\end{array}$} & $\begin{array}{l}\text { dendritic, } \\
\text { variably rimed }\end{array}$ & $\mathrm{R} 1$ & $\begin{array}{l}901,760,577,537,527, \\
\text { 513, 507, 497, 491, } \\
\text { 441, 435, 432, 431, } \\
\text { 430, 423, 421, 419, } \\
\text { 416, 416, 386, 378, } \\
377,370,356,348, \\
341,306,303,300, \\
299,285,267,237, \\
236,234,233,230, \\
206,189\end{array}$ & $2 \mathrm{dc}, 2 \mathrm{bk}$ & $396 \pm 145$ & $0.129 \pm 0.049$ \\
\hline & $\begin{array}{l}\text { columns, } \\
\text { bullets rosettes }\end{array}$ & $\mathrm{R} 2$ & $\begin{array}{l}730,727,687,664,654, \\
644,572,564,534, \\
530,516,505,501, \\
475,434,427,421, \\
418,411,408,381, \\
380,379,371,334, \\
318,315,303,228,226\end{array}$ & $2 \mathrm{dc}, 2 \mathrm{bk}$ & $469 \pm 141$ & $0.156 \pm 0.054$ \\
\hline & $\begin{array}{l}\text { small plates, } \\
\text { needles and } \\
\text { columns }\end{array}$ & R3 & $\begin{array}{l}639,605,571,566, \\
534,528,466,461, \\
460,445,437,428, \\
400,400,394,371, \\
369,348,346,334, \\
323,318,316,316, \\
307,304,303,292, \\
290,274,271,267, \\
260,255,255,240, \\
229,204,192,160,131\end{array}$ & $2 \mathrm{dc}, 2 \mathrm{bk}$ & $356 \pm 122$ & $0.184 \pm 0.075$ \\
\hline & wet snow & $\mathrm{R} 4$ & $549,221,215$ & - & $328 \pm 91$ & $0.215 \pm 0.144$ \\
\hline \multirow[t]{2}{*}{$\begin{array}{l}\text { Aged snow, } \\
\text { no more } \\
\text { recognizable } \\
\text { particles A }\end{array}$} & mostly rounded grains & A1 & $\begin{array}{l}382,350,346,319, \\
306,261,258,253, \\
252,246,242,235, \\
220,200,196,182, \\
171,170,165,161, \\
154,152,151,151, \\
139,136,134,134, \\
133,132,130,118\end{array}$ & $\begin{array}{l}3 \mathrm{sr}, 31 \mathrm{r}, \\
3 \mathrm{mx}, 9 \mathrm{wc}\end{array}$ & $206 \pm 74$ & $0.340 \pm 0.101$ \\
\hline & mostly faceted crystals & $\mathrm{A} 2$ & $\begin{array}{l}450,371,299,283, \\
272,268,260,253, \\
233,232,230,228, \\
219,213,194,192 \\
188,180,174,163 \\
154,154,153,153 \\
149,148,147,145, \\
145,133,131,131 \\
129,124,123,120 \\
119,116,114,108, \\
107,99,98,92 \\
90,88,81\end{array}$ & $4 \mathrm{fa}, 4 \mathrm{sf}, 4 \mathrm{mx}$ & $176 \pm 77$ & $0.205 \pm 0.083$ \\
\hline
\end{tabular}


Table 1. (continued)

\begin{tabular}{|c|c|c|c|c|c|c|}
\hline $\begin{array}{l}\text { Snow } \\
\text { Type }\end{array}$ & $\begin{array}{c}\text { Subtype } \\
\text { Description }\end{array}$ & $\begin{array}{c}\text { Subtype } \\
\text { Code }\end{array}$ & $\begin{array}{l}\mathrm{SSA} \\
\mathrm{cm}^{2} / \mathrm{g}\end{array}$ & $\begin{array}{l}\text { ICSSG } \\
\text { Type }\end{array}$ & $\begin{array}{c}\text { Mean } \\
\mathrm{SSA} \pm \sigma_{\mathrm{SSA}}\end{array}$ & $\begin{array}{c}\text { Mean } \\
\text { Density } \pm \sigma_{\text {dens }}\end{array}$ \\
\hline & depth hoar & A3 & $\begin{array}{l}225,222,205,185, \\
162,156,154,153, \\
149,145,144,142 \\
139,139,135,134 \\
130,128,128,122 \\
117,114,114,113 \\
112,108,103,102 \\
101,99,99,98,97 \\
95,94,93,92,91 \\
87,87,86,86,84 \\
83,80,74,72,72\end{array}$ & $5 \mathrm{cp}, 5 \mathrm{dh}$ & $120 \pm 37$ & $0.198 \pm 0.046$ \\
\hline & $\begin{array}{l}\text { melt-freeze } \\
\text { layer or sun crust }\end{array}$ & A4 & $\begin{array}{l}273,265,251,246, \\
\quad 244,243,226, \\
223,207,202,176, \\
160,123,109,95,75,66\end{array}$ & $6 \mathrm{cl}$ & $187 \pm 70$ & $0.254 \pm 0.062$ \\
\hline & melt-freeze, ice crust & A5 & $45,38,23,20,19$ & $6 \mathrm{mf}, 8 \mathrm{il}, 9 \mathrm{mfc}$ & $29 \pm 12$ & $0.155 \pm 0.066$ \\
\hline Surface hoar S & & $\mathrm{S} 1$ & $\begin{array}{l}564,435,336,295 \\
291,289,279,241\end{array}$ & $7 \mathrm{sh}$ & $341 \pm 107$ & 0.104 (1 value) \\
\hline $\begin{array}{l}\text { Airborne or just } \\
\text { wind-blown, W }\end{array}$ & & W1 & $\begin{array}{c}841,801,627,599 \\
534,435,393\end{array}$ & - & $604 \pm 170$ & $0.201 \pm 0.086$ \\
\hline
\end{tabular}

${ }^{\mathrm{a}}$ Mean SSA and density values are given for each subtype.

ICSSG type 1. R stands for recent snow with recognizable particles and corresponds to ICSSG type 2. The shape of R-type particles has undergone visible transformations, but the habit of these particles when they precipitated can still be recognized. A stands for aged snow. The shapes of these crystals have undergone major changes since precipitation and the original crystal shapes cannot be recognized. The A type regroups ICSSG types 3, 4, 5, 6, 9wc and 9mfc. Types $9 \mathrm{rc}$ and $9 \mathrm{sc}$ would probably be included in our A type, but we have not measured the SSA of such snows. S stands for surface hoar and corresponds to ICSSG type $7 \mathrm{sh}$. W stands for windborne snow, sampled while airborne or immediately after deposition. The $\mathrm{W}$ type has no equivalent in the ICSSG classification, although it is probably somewhat related to a $2 \mathrm{bk}$ crystals that would be heavily rounded. Sub types are defined, with F1 for dendritic crystals with all levels of riming, from unrimed to graupel, F2 for columns and bullet rosettes that form in cold $\left(\mathrm{T}<-23^{\circ} \mathrm{C}\right)$ conditions, etc. This is detailed in Table 1. Regarding surface hoar, Legagneux et al. [2002] had only studied feathershaped crystals, classified as S1 type, thus leaving open the possibility of having other surface hoar subtypes as S2, S3, etc. Here we have also sampled cup-shaped surface hoar, but given the limited number of measurements, we prefer for the moment to regroup all surface hoar samples under a single type, $\mathrm{S}$.

[19] The age of R-type crystals ranges from a few hours to a few weeks. The age of A-type crystals can be just a few days and up to several months. Indeed, a wind storm or very high temperature gradient metamorphism can transform a crystal beyond recognition in just a couple of days. On the contrary, in sheltered high accumulation area where temperature gradients remain low, the initial habit of precipitating crystals can be recognized after a month and these snow layers would then be of the R type. Similarly to the ICSSG classification, the aspect of the crystals is the main criterion, not crystal age.

[20] Table 1 includes another subtype not studied by Legagneux et al. [2002]: A5, for snow layers that have undergone extensive melting or numerous melt-freeze cycles. When frozen, this snow type is very hard and cohesive, while type A4 has undergone only slight melting and remains of moderate hardness when frozen.

[21] Table 1 also reports average values and standard deviations of SSA and density. Density was measured for 297 of the 345 samples. It could not be done when layers were too thin, as was the case for surface hoar, whose density could be measured only once.

\subsection{SSA-Density Correlations}

[22] SSA is expected to correlate to some extent to density, as confirmed in Figure 1. Legagneux et al. [2002] proposed fits of SSA-density correlations of the form $\ln (\mathrm{SSA})=\mathrm{A} d+\mathrm{B}$, where $d$ is density and $\mathrm{A}$ and $\mathrm{B}$ are adjustable parameters, because Narita [1971] had proposed this analytical form. However, several empirical fits with simple analytical expressions (exponential, power and linear laws) were tested, and equation (1), with SSA in $\mathrm{cm}^{2} \mathrm{~g}^{-1}$ and $d$ in $\mathrm{g} \mathrm{cm}^{-3}$ was found to have the best correlation coefficient $\left(\mathrm{R}^{2}=0.431\right)$ :

$$
\mathrm{SSA}=-308.2 \ln (d)-206.0 .
$$

[23] Figure 1, however, shows that equation (1) alone is a poor predictor of SSA. The mean error $E_{\text {mean }}$ at the $1 \sigma$ confidence level, obtained using equation (1), and defined as

$$
E_{\text {mean }}=\sqrt{\frac{4}{n} \sum_{n}\left(\mathrm{SSA}_{m}-\mathrm{SSA}_{e q} / \mathrm{SSA}_{m}+\mathrm{SSA}_{e q}\right)^{2}}
$$

where subscripts $m$ and $e q$ refer to values measured and predicted by equation (1), respectively, is $62 \%$. The $E_{\text {mean }}$ value is fairly high and, as already detailed by Legagneux et al. [2002], better predictions are obtained if the snow type is also considered. Figure 2 illustrates the relationship between 


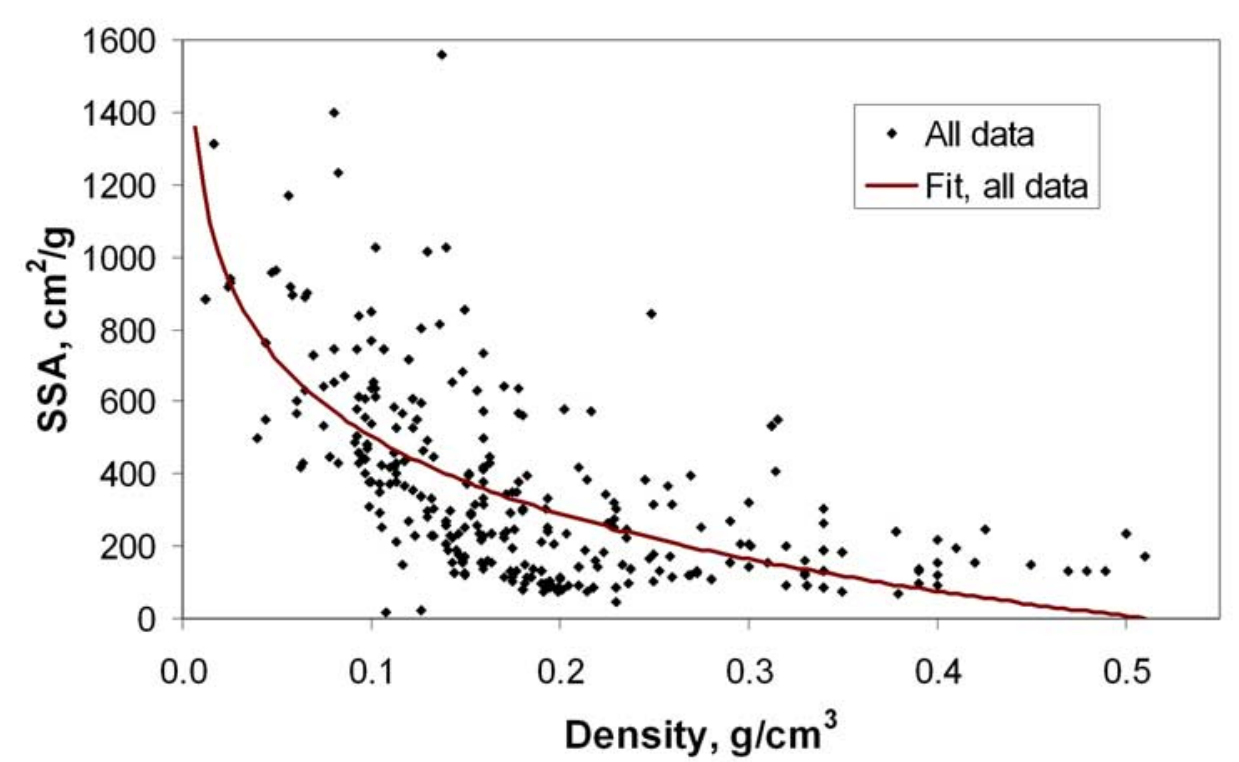

Figure 1. Density-SSA correlation for the 297 snow samples for which both variables were measured. The fit to equation (1) is shown.

density, SSA and snow type: the average SSA and density values, as well as standard deviations, are plotted for all snow subtypes. There is a clear decreasing trend in SSA as snow ages and density increases. Only the A5 type stands out of the main trend, because the dominant process in its evolution, melting, is different from that of the other types, and results in a considerably reduced mean SSA: $29 \mathrm{~cm}^{2} \mathrm{~g}^{-1}$. Density and SSA could be measured together on only three samples of this type, and two of these were during snowmelt in Alaska. Water drained out of the permeable snow, which was originally depth hoar, and the density therefore remained low. We suspect that a wider range of measurements would show a greater range of densities for this type.

[24] The higher SSA values are obviously for fresh snow, and especially for dendritic snow. For dry fresh snow, the mean value is $741 \pm 260 \mathrm{~cm}^{2} \mathrm{~g}^{-1}$. Since our measurement reproducibility is $6 \%$, the variability observed is real and not the result of experimental error. Microscopic observations of fresh snow reveal that an important cause of variability is sublimation during precipitation. For example, dendritic crystals falling in warm air presumably with low relative humidity showed significant rounding and the disappearance of small structures, indicative of sublimation [Nelson,

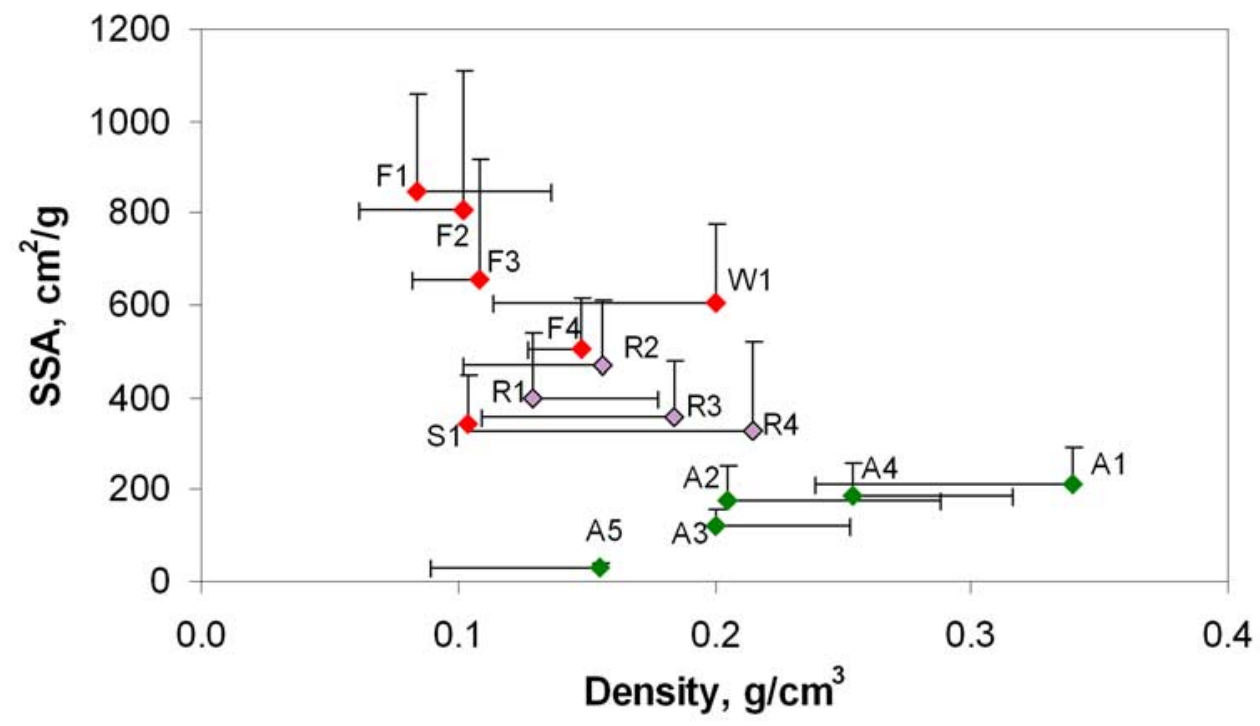

Figure 2. Location of each snow type in a density-SSA plot. Error bars are the variability $(1 \sigma)$ in the SSA of the samples (see Table 1). Only one side of error bars are shown, for clarity. The increase in density and decrease in SSA as snow ages from types F to R and A is clearly visible. A5 stands apart from the trend, because strong melting considerably reduces SSA (see text). 


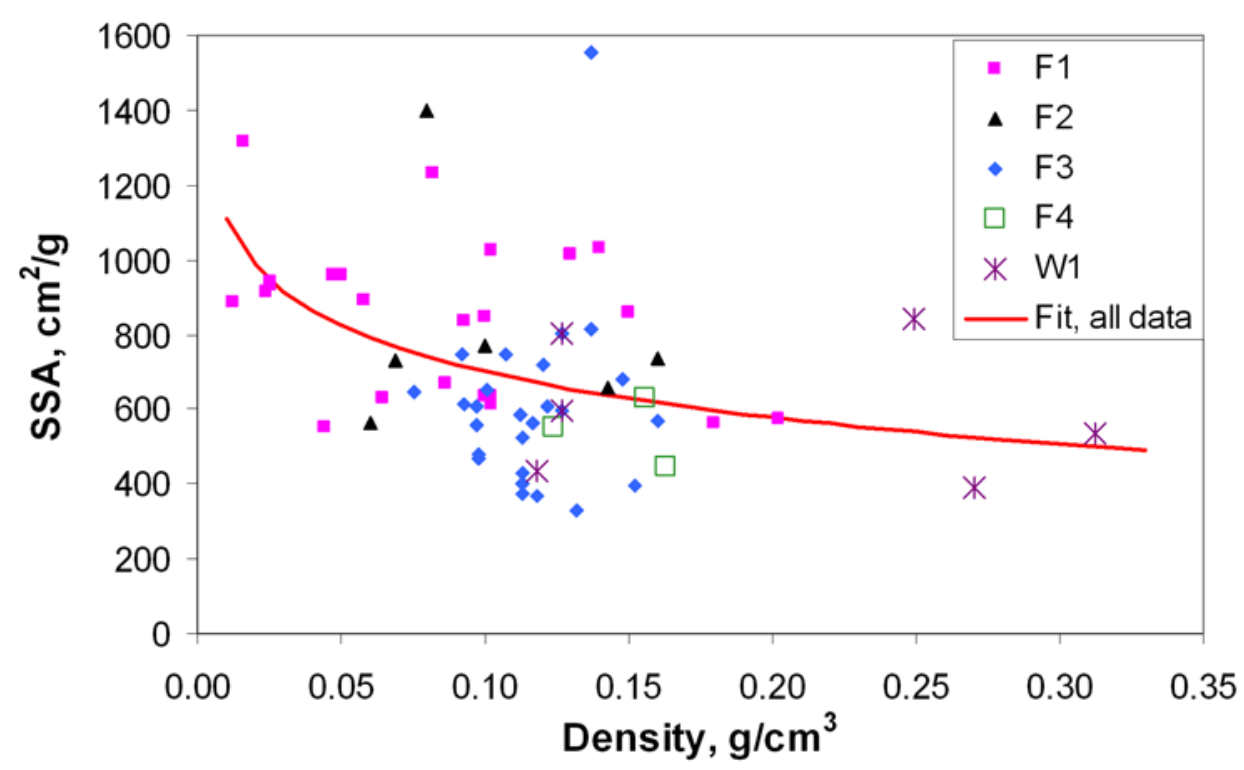

Figure 3. SSA-density correlation for fresh snows. Although subtypes F1 to F4 are located at different places in the graph, they follow a similar trend. Recently wind-blown snow, W1, also follows this trend, and a single equation is proposed to parameterize SSA from the density for all five subtypes.

1998]. This was not observed when crystals fell in air around $-15^{\circ} \mathrm{C}$ [see, e.g., Cabanes et al., 2002, Figure 5]. Other causes of variability are illustrated by the two snowfalls composed of bullet rosettes studied by Cabanes et al. [2002, Figure 1], which had values (corrected for the artifact mentioned above) of 734 and $1401 \mathrm{~cm}^{2} \mathrm{~g}^{-1}$. The values are different because the snowfall with the higher SSA had much smaller crystals, which can be due to a higher number of ice nuclei in the cloud and to a lower moisture content limiting growth. In summary, differences in SSA of fresh snow can be caused by a large number of factors originating in the cloud or during precipitation. At this stage, we cannot propose a prediction of the SSA value of falling snow as a function of meteorological parameters, but we anticipate that further studies may offer predictions of the SSA of falling snow as a function of ice nuclei concentrations, cooling rate, available moisture, and the temperature profile of the atmosphere. At present, the best guess we can propose for dry fresh snow is the average value mentioned above: $741 \mathrm{~cm}^{2} \mathrm{~g}^{-1}$. As shown in Table 1 and Figure 2, considering the type of crystals allows extra precision. For

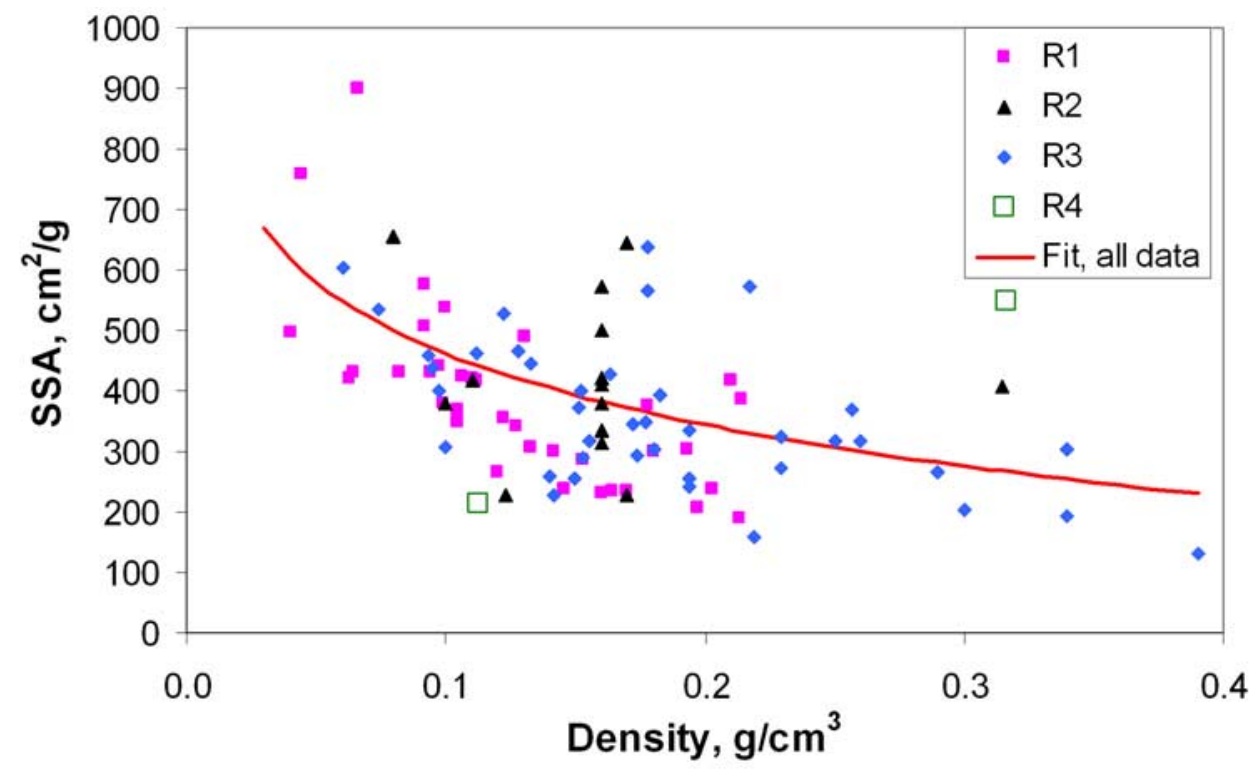

Figure 4. SSA-density correlation for recent snows. Subtypes R1 to R4 are located in roughly similar places in the graph and R1 to R3 follow a single trend. A single equation is proposed to parameterize SSA from the density for all four subtypes. 


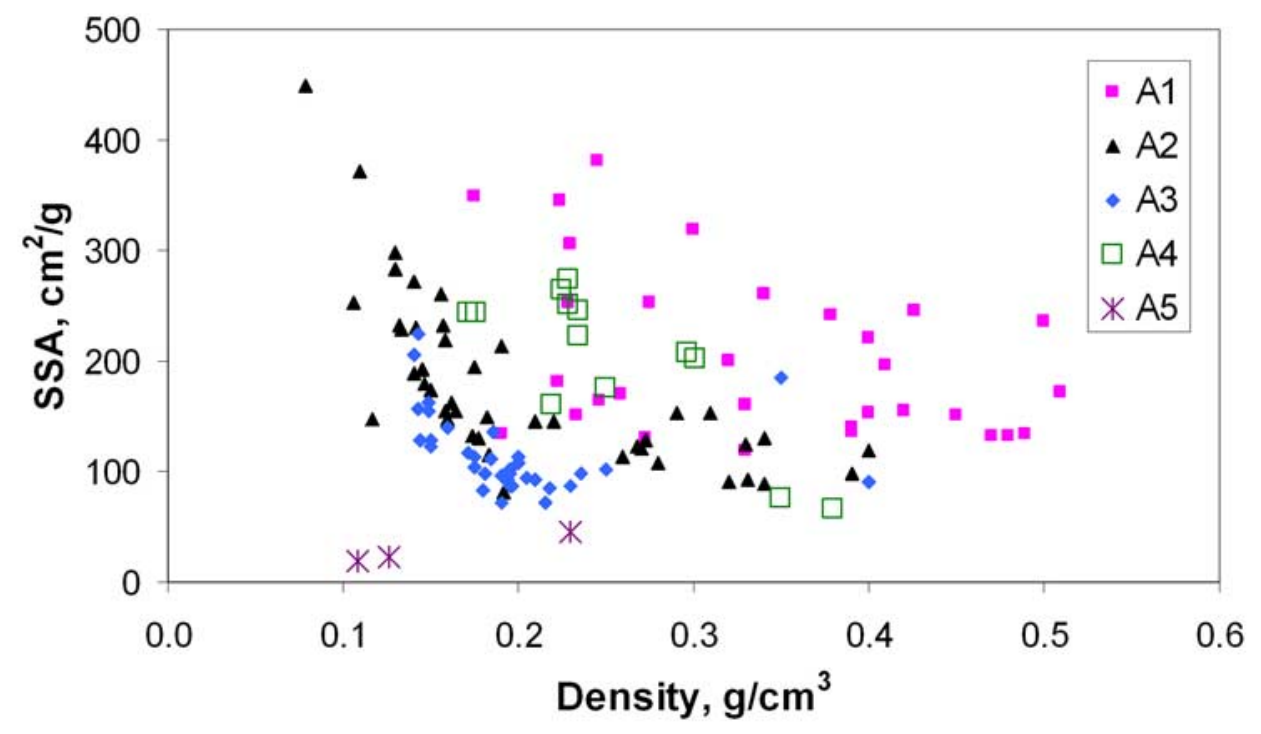

Figure 5. SSA-density correlation for aged snows. All subtypes follow different trends.

an air temperature above $0^{\circ} \mathrm{C}$, we recommend using the average value for the F4 type: $503 \pm 112 \mathrm{~cm}^{2} \mathrm{~g}^{-1}$.

[25] Figure 3 shows that there is a trend, although fairly weak, between SSA and density for fresh snow. The same trend seems to apply to snow at $\mathrm{T}>0^{\circ} \mathrm{C}$ and at $\mathrm{T}<0^{\circ} \mathrm{C}$. It also applies to recently windblown snow. As in Figure 1 and for data discussed later, several empirical equations were tested to fit the data. Overall, equations of the form SSA = $\mathrm{A} \ln (d)+\mathrm{B}$ had the best correlation coefficients. If the density of fresh or recently wind-blown snow is known, we propose to parameterize its SSA in models as

$$
\mathrm{SSA}_{\mathrm{F}, \mathrm{W}}=-174.13 \ln (d)+306.4,
$$

with SSA in $\mathrm{cm}^{2} \mathrm{~g}^{-1}$ and $d$ in $\mathrm{g} \mathrm{cm}^{-3}$. The correlation coefficient is $\mathrm{R}_{\mathrm{F}, \mathrm{W}}^{2}=0.165$ and the mean error $E_{\text {mean }}$ made using equation (3) to predict SSA is $30 \%$.

[26] Likewise, Figure 4 shows that all recent snows seem to follow a single trend, and we propose that the SSA of snows of the R type be parameterized as

$$
\mathrm{SSA}_{\mathrm{R}}=-160.51 \ln (d)+70.1 .
$$

[27] The correlation coefficient is $\mathrm{R}_{\mathrm{R}}^{2}=0.262$ and the mean error made using equation (4) to predict SSA is $31 \%$. If data from subtypes R1 and R3 are fitted separately, we obtain $R_{R 1}^{2}=0.501$ and $R_{R 3}^{2}=0.364$. However, since we recommend using a single equation for the $\mathrm{F}$ subtypes, there is little point in proposing different equations for the $\mathrm{R}$ subtypes.

[28] Aged snow subtypes, however, definitely follow different trends, as visible in Figure 5. Figure 6 shows the SSA-density correlation for the A1 subtype (rounded grains). The equation for all $\mathrm{A} 1$ data, with $\mathrm{R}_{\mathrm{A} 1}^{2}=0.182$ and $E_{\text {mean }}=31 \%$ is

$$
\mathrm{SSA}_{\mathrm{A} 1}=-102.31 \ln (d)+88.9 .
$$

[29] However, Figure 6 shows that three different trends can be identified for tundra windpacks, Alpine snowpacks and the snow that was allowed to accumulate on tables in Alaska. We suggest that this is related to wind action. In the Arctic, the tundra snowpack is largely shaped by wind whose speed can exceed $30 \mathrm{~m} \mathrm{~s}^{-1}$ [e.g., Dominé et al., 2002], snow crystals are broken up and sublimate before deposition, leading to hard windpacks with small grains, and thus of fairly high SSA. Their low permeability [Albert et al., 2002] impedes water vapor transport and grain growth, so that we speculate that the rate of decrease of their SSA is low. In the French Alps, wind is present but its action is reduced compared to the Arctic because storms are less violent and accumulation is much greater. Some layers are exposed to wind, while others are never affected, which accounts for a greater range of SSA values. The snow is less dense, and we speculate that the greater permeability of the snowpack allows higher rates of SSA decrease. The snow that accumulated on tables in Alaska was protected from wind action by plastic sheets on the side. Wind speed was almost always very low $\left(<3 \mathrm{~m} \mathrm{~s}^{-1}\right)$ during these experiments anyway [Taillandier et al., 2006] (see also http:// climate.gi.alaska.edu). Thus the interest of these experiments is that they represent the lower limit of wind action in the formation and evolution of layers with rounded grains. We propose the following equations:

$$
\begin{gathered}
\mathrm{SSA}_{\mathrm{A} 1, \text { tundra }}=-223.53 \ln (d)+0.6 \\
\mathrm{SSA}_{\mathrm{A} 1, \text { Alpine }}=-313.17 \ln (d)+160.1 .
\end{gathered}
$$

[30] These equations have $\mathrm{R}^{2}$ values of 0.562 and 0.742 and $E_{\text {mean }}$ values of $22 \%$ and $20 \%$ respectively. Regarding the Alaska table experiments, there are too few data to propose a correlation. The most reasonable proposition with the data available is probably the average value, $155 \mathrm{~cm}^{2} \mathrm{~g}^{-1}$, 


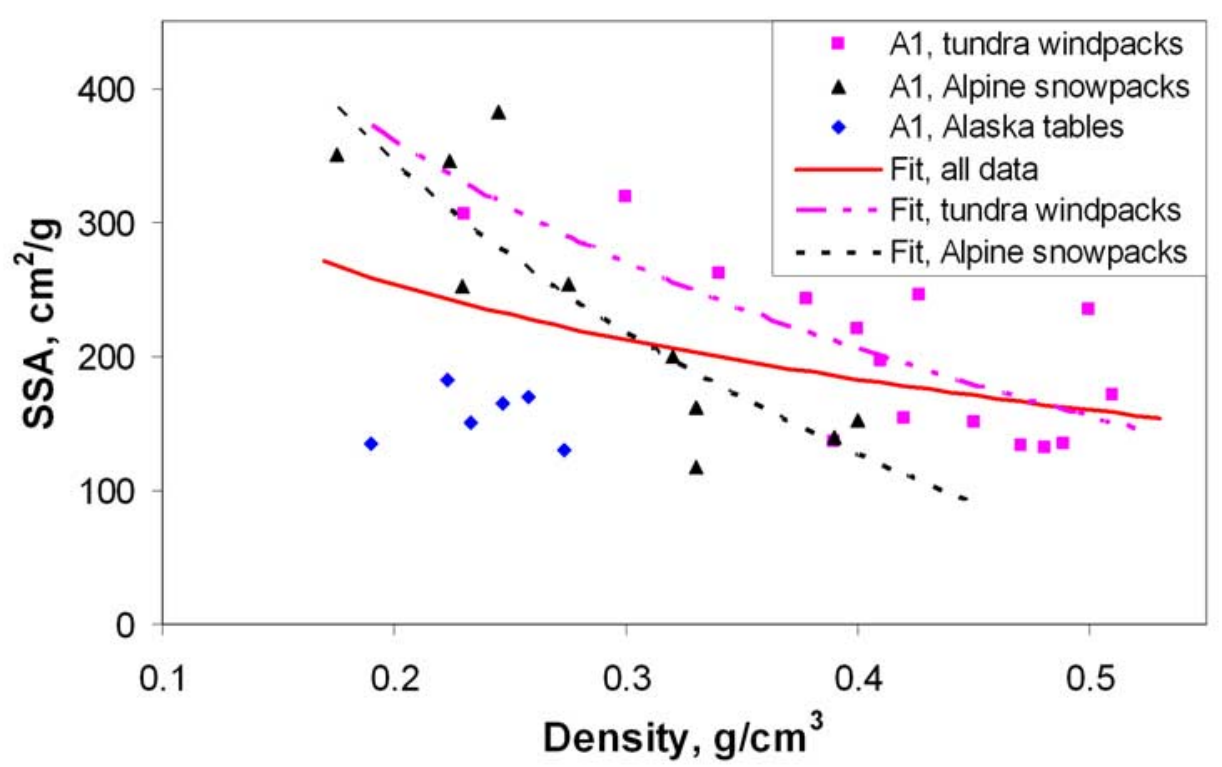

Figure 6. SSA-density correlation for the A1 subtype (rounded grains). Three classes can be seen within this subtype, and correlations are proposed for two of these.

independent of density, resulting in $E_{\text {mean }}=12 \%$. An ideal parameterization of the SSA of the A1 subtype should include a wind action parameter, and we speculate that for each wind speed, a different curve would be obtained in Figure 6. The curve would be lower for lower wind speed values; that is, SSA values are increased by higher wind speeds. Although it would clearly be preferable to know the wind speed under which each layer formed to evaluate its SSA, the statistical nature of our approach does not make this an obligation. All that is needed is to know the snowpack type, i.e., to make a cursory observation of the snowpack or to have the knowledge of basic climate data, as snowpack types are determined by climate [Sturm et al., 1995]. In the absence of details on wind conditions, we recommend the use of equation (5). For tundra windpacks, we suggest testing equation (6), but the user is warned that we feel more data are needed to reach a level of confidence we consider as satisfactory. The same applies for the Alpine snowpacks and equation (7).

[31] To a first approximation, all data within the A2 subtype follow the same trend (Figure 7), although it is clear that in the taiga snowpack, samples have a lower density and a wider range of SSA. The correlation is, with $\mathrm{R}_{\mathrm{A} 2}^{2}=0.594$ and $E_{\text {mean }}=27 \%$ :

$$
\mathrm{SSA}_{\mathrm{A} 2}=-150.67 \ln (d)-73.5
$$

[32] A closer examination shows that two different trends can actually be detected. The taiga samples appear to have their own trend. The correlation is, with $\mathrm{R}_{\mathrm{A} 2 \text {,taiga }}^{2}=0.692$ and $E_{\text {mean }}=21 \%$,

$$
\mathrm{SSA}_{\mathrm{A} 2, \text { taiga }}=-345.4 \ln (d)-457.2 .
$$

[33] The second trend regroups the Alpine and tundra snowpacks, as well as samples from the Alaska tables. The correlation is, with $\mathrm{R}_{\mathrm{A} 2 \text {, alp.tun.tab }}^{2}=0.663$ and $E_{\text {mean }}=16 \%$,

$$
\mathrm{SSA}_{\mathrm{A} 2, \text { alp.tun.tab }}=-101.0 \ln (d)+0.9 \text {. }
$$

[34] The reason why there are two different trends in the A2 type is probably because the temperature gradient is much greater in the taiga snowpack [Sturm and Benson, 1997]. These temperature gradients generate enormous upward water vapor fluxes that reduce the density of the lower layers of the taiga snowpack, whose density stays below 0.20 [Sturm and Benson, 1997; Taillandier et al., 2007]. After 2 to 3 weeks, faceted crystals (A2 type) of the taiga snowpack transform into depth hoar. On the contrary, in the Alpine and tundra snowpacks, the snow is much less permeable, temperature gradients are usually significantly lower, so that the large water vapor fluxes necessary to maintain a low density or to decrease it are usually not there. Hence taiga samples are all at low density $(d<0.20)$ while all but one of the Alpine and tundra samples have higher density $(d>0.20)$. The Alaska table samples were left to accumulate without any wind compaction at all, and the snowpack being thin [Sturm and Benson, 1997; Taillandier et al., 2006], the load did not lead to much compaction. Faceted crystals did form on the tables because of transient gradients in late winter, when the sun started heating surface snow. Interestingly, if the data from the tables are removed, the SSA values predicted by equation (10) change by less that $1 \%$, confirming that those tables data do follow the Alpine and tundra trend very closely.

[35] In summary, from our data we propose to apply equation (9) for faceted crystals having high temperature gradients generating large upward vapor fluxes. These faceted crystals are bound to transform into depth hoar rapidly, within three weeks at the most. We suggest using equation (10) for snowpack where the temperature gradient will not generate the large water vapor fluxes mentioned 


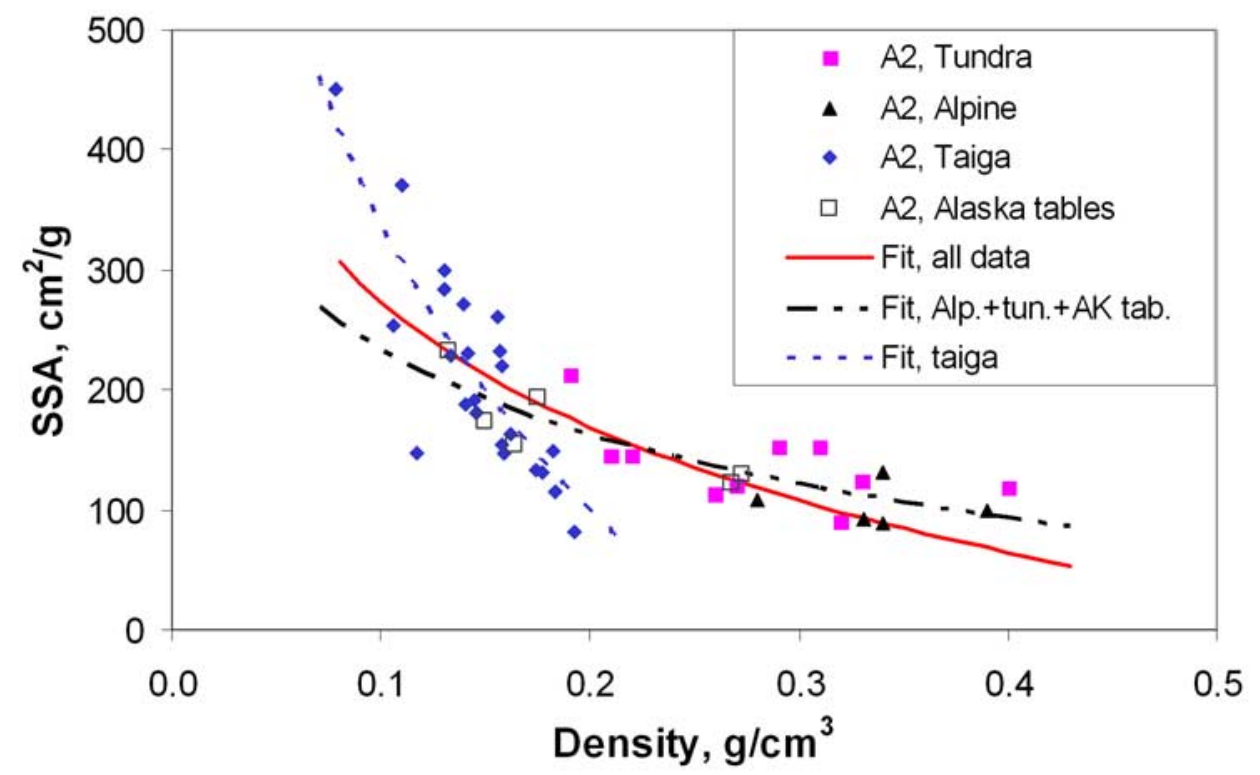

Figure 7. SSA-density correlation for the A2 subtype (faceted crystals). A fit describing all the data is shown. Two different trends can be observed, for which separate fits are proposed: (1) taiga snow, all for densities less than 0.2, and (2) Alpine and tundra snow, at higher density. Samples from the Alaska tables appear to follow the same trend as the latter type, and has been included in it.

above. These faceted crystals in general will never transform into depth hoar.

[36] Depth hoar data (A3 subtype) are reported in Figure 8, and show a lot of scatter, leading to a correlation $\mathrm{R}_{\mathrm{A} 3}^{2}=0.169$ and $E_{\text {mean }}=28 \%$ for the equation

$$
\mathrm{SSA}_{\mathrm{A} 3}=-68.862 \ln (d)+1.2 .
$$

[37] Again, the taiga data alone show a well defined trend, with $\mathrm{R}_{\mathrm{A} 3 \text {, taiga }}^{2}=0.658$ and $E_{\text {mean }}=23 \%$ for the equation

$$
\mathrm{SSA}_{\mathrm{A} 3, \text { taiga }}=-206.48 \ln (d)-241.9,
$$

while the Alpine and tundra data show little correlation between SSA and density, with $\mathrm{R}_{\mathrm{A} 3 \text {, alp.tun }}^{2}=0.032$ and $E_{\text {mean }}=$ $20 \%$, the equation being

$$
\mathrm{SSA}_{\mathrm{A} 3, \text { alp.tun }}=-23.97 \ln (d)+87.2 \text {. }
$$

[38] Given the poor correlation, one might as well use the average value $\mathrm{SSA}_{\mathrm{A} 3 \text {,alp.tun }}=135 \mathrm{~cm}^{2} \mathrm{~g}^{-1}$, resulting in $E_{\text {mean }}=23 \%$. We also note that the lowest 2 values (87 and 91) are the only Alpine data for this class: depth hoar is not common in the French Alps. In many places, it does not form every year.

[39] We again attempt to understand why there are 2 distinct trends for depth hoar. In taiga snowpacks, depth hoar forms directly from the rapid metamorphism of precipitation under high temperature gradients. In vegetated areas such as the taiga, wind has little effect on snow compaction. This, combined with the high water vapor flux mentioned above, prevents snowpack densification. As a result, the ultimate stage of the taiga snowpack is what we may call terminal depth hoar, which has a density around $0.2 \mathrm{~g} \mathrm{~cm}^{-3}$ and a SSA of about $75 \mathrm{~cm}^{2} \mathrm{~g}^{-1}$.

[40] In the tundra and Alpine snowpacks, depth hoar formation usually goes through the intermediate stage of a windpack, whose density is often in the range 0.35 to $0.5 \mathrm{~g} \mathrm{~cm}^{-3}$. Depth hoar formation is then usually associated with mass loss by sublimation from the warmer snow layer to the colder atmosphere in the fall [e.g., Dominé et al., 2002, and references therein]. Depth hoar does not need a low-density snowpack to form, as suggested by Marbouty [1980], who proposed an upper limit to snow density of 0.35 for depth hoar formation. Near Barrow, Alaska, we have observed depth hoar that had formed in very dense basal ice layers, in frozen percolation channels, and in hard windpacks. Depth hoar density can reach 0.4 in the tundra snowpack. In the accumulation zone of Alpine glaciers, we have also observed melt layers from the previous season transformed into depth hoar of density greater than 0.4 , in late fall. In summary, because the tundra and Alpine depth hoar goes through the intermediate stage of a dense layer, and because dense hoar can form in dense snow given sufficiently high temperature gradients (greater than $100^{\circ} \mathrm{C} / \mathrm{m}$ ), tundra and Alpine dense hoar usually have a density greater than 0.2 , while taiga depth hoar has a density less than 0.22 . Hence two distinct trends exist in density-SSA correlations for depth hoar. The terminal SSA value for depth hoar appears to be around $75 \mathrm{~cm}^{2} \mathrm{~g}^{-1}$ in the taiga, and $100 \mathrm{~cm}^{2}$ $\mathrm{g}^{-1}$ in the tundra. We only have two Alpine values and cannot draw conclusions for this snowpack type.

[41] Data for aged snow having undergone light melting, A4, are reported in Figure 9. All data are from the Alps, except one sample from the taiga snowpack in Alaska. 


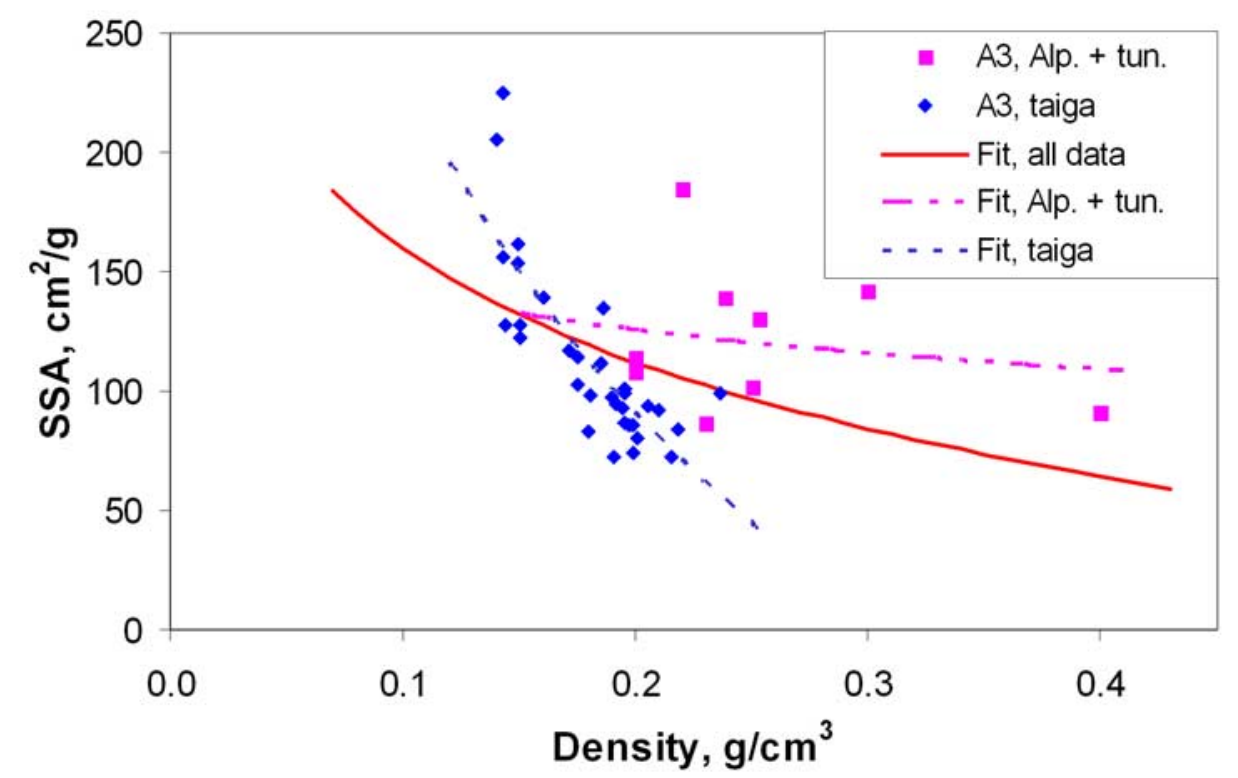

Figure 8. SSA-density correlation for the A3 subtype (depth hoar). A fit describing all the data is shown. Two different trends can be observed, for which separate fits are proposed: (1) taiga snow, with densities less than 0.22 for all but one sample, and (2) Alpine and tundra snow, with densities between 0.2 and 0.4. See text for details.

Given the available data, we can only propose the existence of one trend, with $\mathrm{R}_{\mathrm{A} 4}^{2}=0.578$ and $E_{\text {mean }}=27 \%$ for the equation

$$
\mathrm{SSA}_{\mathrm{A} 4}=-217.3 \ln (d)-101.4
$$

[42] There is significant scatter around the fit, in part caused by variable degrees of melting and the occurrence or absence of percolation.
[43] We only have five SSA values for the A5 type (extensive melting leading to the formation of a solid icelike layer, when frozen), four of them from the Alaska taiga. Two of those are thin surface melt layers that formed in early fall. They had SSAs of 20 and $38 \mathrm{~cm}^{2} \mathrm{~g}^{-1}$ and their density could not be measured. The other two are from the late stages of melting of the snowpack in April. They had SSAs of 19 and $23 \mathrm{~cm}^{2} \mathrm{~g}^{-1}$ and densities around 0.12 . The fifth value is from the Alps, with SSA $=45 \mathrm{~cm}^{2} \mathrm{~g}^{-1}$ and

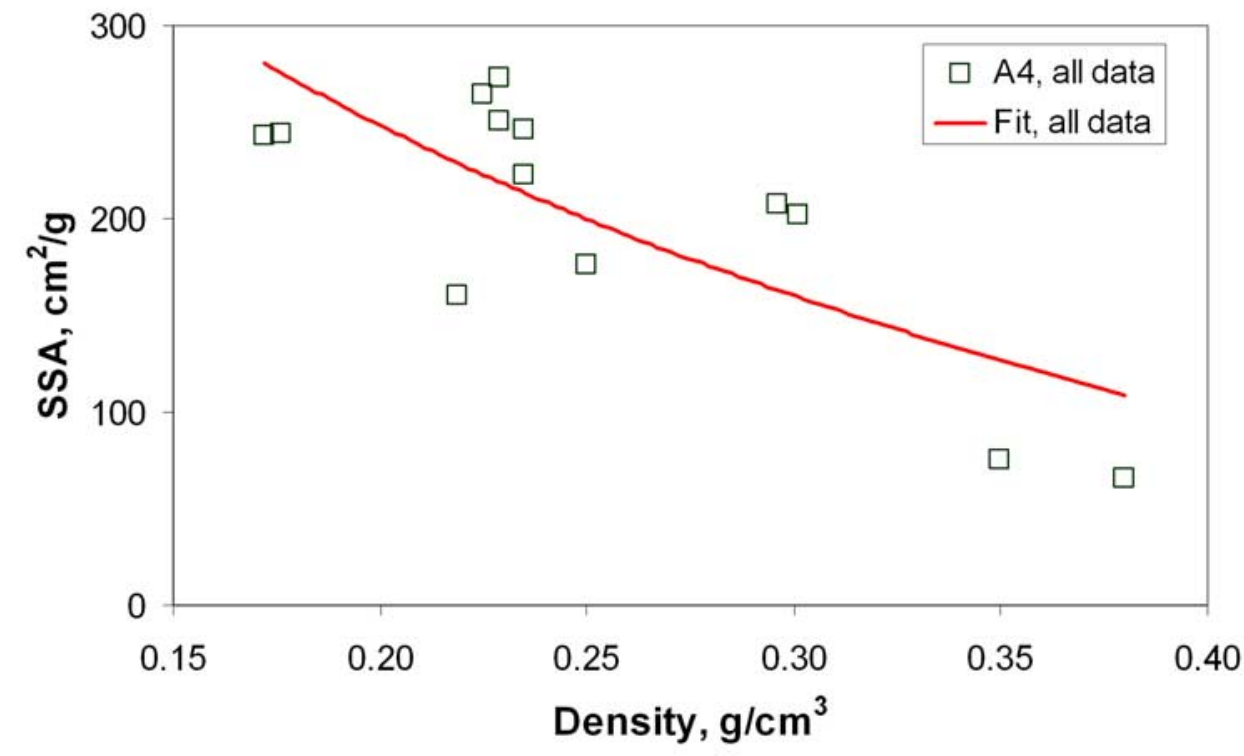

Figure 9. SSA-density correlation for the A4 subtype (wet aged snow). A fit describing all the data is shown. 
Table 2. Three Proposed Parameterizations of Snow SSA, With Increasing Sophistication ${ }^{\mathrm{a}}$

\begin{tabular}{|c|c|c|c|}
\hline Snow Type & Parameterization 1 & Parameterization 2 & Parameterization 3 \\
\hline F1 & 849 & $\mathrm{SSA}_{\mathrm{F}, \mathrm{W}}=-174.1 \ln (d)+306.4$ & $\mathrm{SSA}_{\mathrm{F}, \mathrm{W}}=-174.1 \ln (d)+306.4$ \\
\hline F2 & 809 & $\mathrm{SSA}_{\mathrm{F}, \mathrm{W}}=-174.1 \ln (d)+306.4$ & $\mathrm{SSA}_{\mathrm{F}, \mathrm{W}}=-174.1 \ln (d)+306.4$ \\
\hline F3 & 658 & $\mathrm{SSA}_{\mathrm{F}, \mathrm{W}}=-174.1 \ln (d)+306.4$ & $\mathrm{SSA}_{\mathrm{F}, \mathrm{W}}=-174.1 \ln (d)+306.4$ \\
\hline F4 & 503 & $\mathrm{SSA}_{\mathrm{F}, \mathrm{W}}=-174.1 \ln (d)+306.4$ & $\mathrm{SSA}_{\mathrm{F}, \mathrm{W}}=-174.1 \ln (d)+306.4$ \\
\hline R1 & 396 & $\mathrm{SSA}_{\mathrm{R}}=-160.5 \ln (d)+70.1$ & $\mathrm{SSA}_{\mathrm{R}}=-160.5 \ln (d)+70.1$ \\
\hline R2 & 469 & $\mathrm{SSA}_{\mathrm{R}}=-160.5 \ln (d)+70.1$ & $\mathrm{SSA}_{\mathrm{R}}=-160.5 \ln (d)+70.1$ \\
\hline R3 & 356 & $\mathrm{SSA}_{\mathrm{R}}=-160.5 \ln (d)+70.1$ & $\mathrm{SSA}_{\mathrm{R}}=-160.5 \ln (d)+70.1$ \\
\hline R4 & 328 & $\mathrm{SSA}_{\mathrm{R}}=-160.5 \ln (d)+70.1$ & $\mathrm{SSA}_{\mathrm{R}}=-160.5 \ln (d)+70.1$ \\
\hline A1 & 206 & $\mathrm{SSA}_{\mathrm{A} 1}=-102.3 \ln (d)+88.9$ & $\begin{array}{l}\mathrm{SSA}_{\mathrm{A} 1, \text { tundra }}=-223.5 \ln (d)+0.6 \\
\mathrm{SSA}_{\mathrm{A} 1, \mathrm{Alpine}}=-313.2 \ln (d)-160.1\end{array}$ \\
\hline $\mathrm{A} 2$ & 176 & $\mathrm{SSA}_{\mathrm{A} 2}=-150.7 \ln (d)-73.5$ & $\begin{array}{l}\mathrm{SSA}_{\mathrm{A} 2 \text {,taiga }}=-345.4 \ln (d)-457.2 \\
\quad \mathrm{SSA}_{\mathrm{A} 2 \text {,alp.tun. }}=-101.0 \ln (d)+0.9\end{array}$ \\
\hline A3 & 120 & $\mathrm{SSA}_{\mathrm{A} 3}=-68.86 \ln (d)+1.2$ & $\begin{array}{l}\mathrm{SSA}_{\mathrm{A} 3, \text { taiga }}=-206.5 \ln (d)-241.9 \\
\quad \mathrm{SSA}_{\mathrm{A} 3, \text { alp.tun }}=135\end{array}$ \\
\hline A4 & 187 & $\mathrm{SSA}_{\mathrm{A} 4}=-217.3 \ln (d)-101.4$ & $\mathrm{SSA}_{\mathrm{A} 4}=-217.3 \ln (d)-101.4$ \\
\hline A5 & 29 & 29 & 29 \\
\hline S1 & 341 & 341 & 341 \\
\hline W1 & 604 & $\mathrm{SSA}_{\mathrm{F}, \mathrm{W}}=-174.1 \ln (d)+306.4$ & $\mathrm{SSA}_{\mathrm{F}, \mathrm{W}}=-174.1 \ln (d)+306.4$ \\
\hline
\end{tabular}

${ }^{\mathrm{a}} \mathrm{SSA}$ is in $\mathrm{cm}^{2} \mathrm{~g}^{-1}$ and snow density, $d$, is in $\mathrm{g} \mathrm{cm}^{-3}$.

$d=0.23$. On the basis of this limited data set, we recommend, with $E_{\text {mean }}=35 \%$, the average value

$$
\mathrm{SSA}_{\mathrm{A} 5}=29 \mathrm{~cm}^{2} \mathrm{~g}^{-1}
$$

while we do realize that the degree of melting and percolation, as well as the density, could affect SSA. However, we expect the SSA of A5 samples to be always low, and in any case much lower than $100 \mathrm{~cm}^{2} \mathrm{~g}^{-1}$.

[44] Regarding the S1 type (surface hoar) we have 3 values from the Arctic $\left(564,336,289 \mathrm{~cm}^{2} \mathrm{~g}^{-1}\right)$, two values from the Alps $\left(435,291 \mathrm{~cm}^{2} \mathrm{~g}^{-1}\right)$ and 3 values from the Alaska taiga $\left(295,279,241 \mathrm{~cm}^{2} \mathrm{~g}^{-1}\right.$, but only one density value, $0.10 \mathrm{~g} \mathrm{~cm}^{-3}$ for the Alaska sample with SSA of $295 \mathrm{~cm}^{2} \mathrm{~g}^{-1}$. This measurement was performed by placing a board on the surface of the snow prior to surface hoar formation. Hence we cannot propose a SSA-density correlation for surface hoar, and only recommend, with $E_{\text {mean }}=26 \%$, the average value

$$
\mathrm{SSA}_{\mathrm{S} 1}=341 \mathrm{~cm}^{2} \mathrm{~g}^{-1}
$$

\section{Summary and Future Work}

[45] We report here 345 snow SSA values and show in Figure 1 that there is a correlation between SSA and density, described by equation (1). However, given the scatter around equation (1), and the clear dependence of SSA on snow type, we feel that using equation (1) to predict snow SSA in snow models is not satisfactory, and we propose three types of parameterizations that take into account snow type, as summed up in Table 2.

[46] The most basic parameterization is based on Table 1 and Figure 2, where only the average SSA value for each snow subtype is used, independently of density. The intermediate version uses only one correlation for each snow subtype. The most sophisticated version is different from the previous one in its treatment of some aged snows only, i.e., for the A1 (rounded grains), A2 (faceted crystals) and
A3 (depth hoar) subtypes. To sum up the differences between parameterizations 2 and 3, let us just say that parameterization 3 takes into account the effect of wind on the SSA-density correlations of aged snows. This effect is different for, on the one hand, the taiga snowpack where the vegetation shelters the snow from wind compaction and for, on the other hand, the tundra and Alpine snowpacks where wind densifies the snowpacks, reduces its permeability and the water vapor fluxes through it.

[47] Despite the 345 SSA measurements presented here, these parameterizations still suffer from numerous weaknesses. First of all, it would be desirable to predict the SSA of fresh precipitated snow from the meteorological and atmospheric conditions that generated it: temperature and moisture content of the cloud, concentration of ice nuclei, rate of cooling, and vertical temperature and humidity profiles in the atmosphere. Understanding these issues is a distant goal, as most meteorological models do not have a detailed parameterization of ice nuclei.

[48] Second, we only have one measurement of the density of surface hoar (type S1). Under cold conditions $\left(\mathrm{T}<-35^{\circ} \mathrm{C}\right)$, such as those prevailing in the Arctic, surface hoar forms such thin layers that density measurements appear illusory. We believe that it would be more useful to predict the mass of surface hoar forming, and to study the effect of temperature and growth rate on SSA.

[49] Third, we have few data on wet snow. The fresh (F type) and recent ( $\mathrm{R}$ type) wet snows studied all had low degrees of melting that did not really affect the aspect of crystals during field observations. Measurements of snow more affected by melting are desirable. We also clearly have too few studies of ripening snowpacks, and we do need to perform measurements on dense wet snows.

[50] Finally, the faceted crystals (A2 subtype) of the tundra snowpacks that we studied are all spring layers that were only lightly compacted by weak winds and that underwent gradient metamorphism near the surface of the snowpack. These snows did not turn into depth hoar during 24 days of monitoring in the spring, and their behavior may be different from that of the faceted crystals that precede 
depth hoar formation at the base of the tundra snowpack in the fall. Fall measurement campaigns in the Arctic are needed to fill that data gap.

[51] Acknowledgments. This work was carried out over many years and benefited from many funding sources. Among these are: CNRS (PNCA program) for work in the Alps, IPEV (French Polar Institute) for work at Alert and Ny Ålesund, and funds from the Chapman Chair, given by Norbert Untersteiner, and from the International Arctic Research Center for work in Alaska. So many people assisted us in so many ways that it is not possible to name them all. We do wish to mention, however, Axel Cabanes, Loïc Legagneux, Thomas Lauzier, and Elodie Bonnaud for help with field trips, sample collection and measurements, Al Gallant and Peter Brickel for logistical help at Alert, AWI staff and Roberto Sparapani for assistance at Ny Ålesund, and Bill Hauer for providing a wonderful sampling site in Alaska.

\section{References}

Albert, M. R., and E. F. Shultz (2002), Snow and firn properties and airsnow transport processes at Summit, Greenland, Atmos. Environ., 36, $2789-2797$.

Albert, M. R., A. M. Grannas, J. W. Bottenheim, P. B. Shepson, and F. E. Perron Jr. (2002), Processes and properties of snow-air transfer in the high Arctic with application to interstitial ozone at Alert, Canada, Atmos. Environ., 36, 2779-2787.

Alley, R. B., et al. (1997), Visual-stratigraphic dating of the GISP2 ice core: Basis, reproducibility, and application, J. Geophys. Res., 102, 26,36726,381 .

Aoki, T., T. Aoki, M. Fukabori, A. Hachikubo, Y. Tachibana, and F. Nishio (2000), Effects of snow physical parameters on spectral albedo and bidirectional reflectance of snow surface, J. Geophys. Res., 105, 10,21910,236 .

Brun, E., P. David, M. Sudul, and G. Brunot (1992), Numerical model to simulate snow-cover stratigraphy for operational avalanche forecasting, J. Glaciol., 128, 13-22.

Brunauer, S., P. H. Emmet, and E. Teller (1938), Adsorption of gases in multimolecular layers, J. Am. Chem. Soc., 60, 309-319.

Cabanes, A., L. Legagneux, and F. Dominé (2002), Evolution of the specific surface area and of crystal morphology of Arctic fresh snow during the ALERT2000 campaign, Atmos. Environ., 36, 2767-2777.

Cabanes, A., L. Legagneux, and F. Dominé (2003), Rate of evolution of the specific surface area of surface snow layers, Environ. Sci. Technol., 37, 661-666.

Chaix, L., and F. Dominé (1997), Effect of the thermal history of ice crushed at $77 \mathrm{~K}$ on its surface structure as determined by adsorption of $\mathrm{CH}_{4}$ at low surface coverage, J. Phys. Chem. B, 101, 6105-6108.

Chaix, L., J. Ocampo, and F. Dominé (1996), Adsorption of $\mathrm{CH}_{4}$ on laboratory-made crushed ice and on natural snow at $77 \mathrm{~K}$ : Atmospheric implications, C. R. Acad. Sci., Ser. IIa Sci. Terre Planetes, 322, 609-616.

Colbeck, S., E. Akitaya, R. Armstrong, H. Gubler, J. Lafeuille, K. Lied, D. McClung, and E. Morris (1990), The international classification for seasonal snow on the ground, report, Int. Comm. of Snow and Ice, Int. Assoc. of Sci. Hydrol., Wallingford, U. K.

Daly, G. L., and F. Wania (2004), Simulating the influence of snow on the fate of organic compounds, Environ. Sci. Technol., 38, 4176-4186.

Dang, H., C. Genthon, and E. Martin (1997), Numerical modeling of snow cover over polar ice sheets, Ann. Glaciol., 25, 170-176.

Dominé, F., and P. B. Shepson (2002), Air-snow interactions and atmospheric chemistry, Science, 297, 1506-1510.

Dominé, F., L. Chaix, and L. Hanot (2000), Reanalysis and new measurements of $\mathrm{N}_{2}$ and $\mathrm{CH}_{4}$ adsorption on ice and snow, J. Colloid Interface Sci., 227, 104-110.

Dominé, F., A. Cabanes, A.-S. Taillandier, and L. Legagneux (2001), Specific surface area of snow samples determined by $\mathrm{CH}_{4}$ adsorption at $77 \mathrm{~K}$ and estimated by optical microscopy and scanning electron microscopy, Environ. Sci. Technol., 35, 771-780.

Dominé, F., A. Cabanes, and L. Legagneux (2002), Structure, microphysics, and surface area of the Arctic snowpack near Alert during the ALERT 2000 campaign, Atmos. Environ., 36, 2753-2765.

Domine, F., R. Salvatori, L. Legagneux, R. Salzano, M. Fily, and R. Casacchia (2006), Correlation between the specific surface area and the short wave infrared (SWIR) reflectance of snow, Cold Regions Sci. Technol., 46, 60-68, doi:10.1016/j.coldregions.2006.06.002.

Flanner, M. G., and C. S. Zender (2006), Linking snowpack microphysics and albedo evolution, J. Geophys. Res., 111, D12208, doi:10.1029/ 2005JD006834.

Herbert, B. M. J., C. J. Halsall, S. Villa, K. C. Jones, and R. Kallenborn (2005a), Rapid changes in PCB an OC pesticide concentrations in Arctic snow, Environ. Sci. Technol., 39, 2998-3005.

Herbert, B. M. J., C. J. Halsall, S. Villa, L. Fitzpatrick, K. C. Jones, R. G. M. Lee, and R. Kallenborn (2005b), Polychlorinated naphtalenes in air and snow in the Norwegian Arctic: A local source or an Eastern Arctic phenomenon?, Sci. Total. Environ., 342, 145-160.

Jordan, R. E., J. P. Hardy, F. E. Perron, and D. J. Fisk (1999), Air permeability and capillary rise as measures of the pore structure of snow: an experimental and theoretical study, Hydrol. Processes, 13, 1733-1753.

Legagneux, L., and F. Domine (2005), A mean field model of the decrease of the specific surface area of dry snow during isothermal metamorphism, J. Geophys. Res., 110, F04011, doi:10.1029/2004JF000181.

Legagneux, L., A. Cabanes, and F. Dominé (2002), Measurement of the specific surface area of 176 snow samples using methane adsorption at 77 K, J. Geophys. Res., 107(D17), 4335, doi:10.1029/2001JD001016.

Legagneux, L., T. Lauzier, F. Dominé, W. F. Kuhs, T. Heinrichs, and K. Techmer (2003), Rate of decay of the specific surface area of snow during isothermal experiments and morphological changes studied by scanning electron microscopy, Can. J. Phys., 81, 459-468.

Legagneux, L., A.-S. Taillandier, and F. Domine (2004), Grain growth theories and the isothermal evolution of the specific surface area of snow, J. Appl. Phys., 95, 6175-6184.

Lehning, M., P. Bartelt, B. Brown, C. Fierz, and P. Satyawali (2002), A physical SNOWPACK model for the Swiss avalanche warning Part II: Snow microstructure, Cold Regions Sci. Technol., 35, 147-167.

Marbouty, D. (1980), An experimental study of temperature-gradient metamorphism, J. Glaciol., 26, 303-312.

Narita, H. (1971), Specific surface of deposited snow II, Low Temp. Sci., A29, 69-81.

Nelson, J. (1998), Sublimation of ice crystals, J. Atmos. Sci., 55, 910-919.

Sturm, M., and C. S. Benson (1997), Vapor transport, grain growth and depth-hoar development in the subarctic snow, J. Glaciol., 43, 42-59.

Sturm, M., J. Holmgren, and G. E. Liston (1995), A seasonal snow cover classification system for local to global applications, J. Clim., 8, 12611283.

Taillandier, A.-S., F. Domine, W. R. Simpson, M. Sturm, T. A. Douglas, and K. Severin (2006), Evolution of the Snow Area Index, SAI, of the subarctic snowpack in Central Alaska over a whole season: Consequences for the air to snow transfer of pollutants, Environ. Sci. Technol., 40, 7521-7527, doi:10.1021/es060842j.

Taillandier, A.-S., F. Domine, W. R. Simpson, M. Sturm, and T. A. Douglas (2007), Rate of decrease of the specific surface area of dry snow: Isothermal versus temperature gradient conditions, J. Geophys. Res., doi: $10.1029 / 2006 \mathrm{JF} 000514$, in press.

Warren, S. G. (1982), Optical properties of snow, Rev. Geophys., 20, $67-89$.

F. Domine and A.-S. Taillandier, Laboratoire de Glaciologie et Géophysique de l'Environnement, CNRS, BP 96, F-38402 Saint-Martin d'Hères, France. (florent@lgge.obs.ujf-grenoble.fr)

W. R. Simpson, Geophysical Institute, University of Alaska Fairbanks, 903 Koyukuk Drive, P.O. Box 757320, Fairbanks, AK 99775-7320, USA. 